\title{
Development and Implementation of Air Barrier Systems for New and Existing Buildings
}

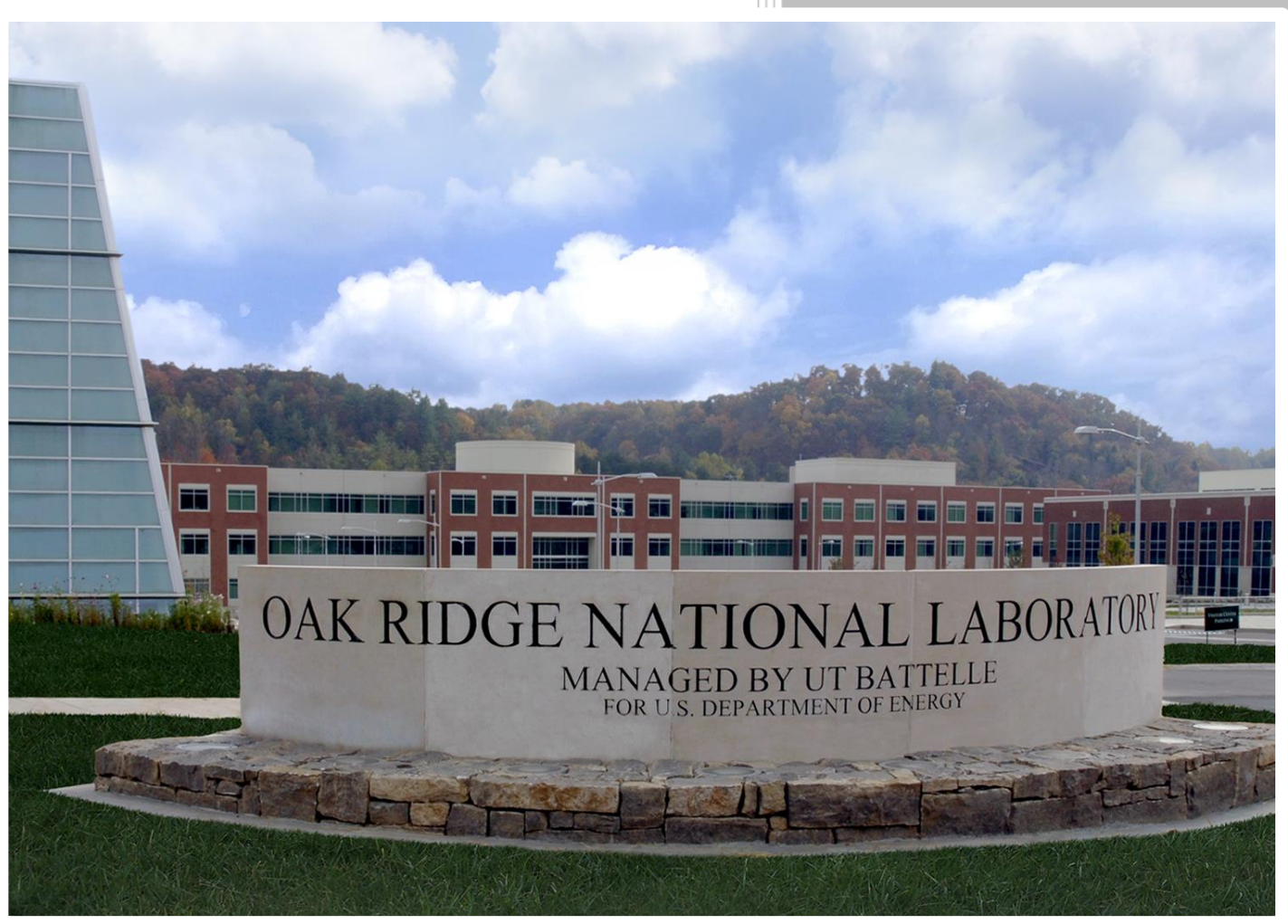

CRADA FINAL REPORT NFE-12-04010 APPROVED FOR PUBLIC RELEASE DISTRIBUTION IS UNLIMITED
Diana E. Hun Andre O. Desjarlais Laverne Dalgleish

December 2017 


\section{DOCUMENT AVAILABILITY}

Reports produced after January 1, 1996, are generally available free via US Department of Energy (DOE) SciTech Connect.

Website http://www.osti.gov/scitech/

Reports produced before January 1, 1996, may be purchased by members of the public from the following source:

National Technical Information Service

5285 Port Royal Road

Springfield, VA 22161

Telephone 703-605-6000 (1-800-553-6847)

TDD 703-487-4639

Fax 703-605-6900

E-mail info@ntis.gov

Website http://www.ntis.gov/help/ordermethods.aspx

Reports are available to DOE employees, DOE contractors, Energy Technology Data Exchange representatives, and International Nuclear Information System representatives from the following source:

Office of Scientific and Technical Information

PO Box 62

Oak Ridge, TN 37831

Telephone 865-576-8401

Fax 865-576-5728

E-mail reports@osti.gov

Website http://www.osti.gov/contact.html

This report was prepared as an account of work sponsored by an agency of the United States Government. Neither the United States Government nor any agency thereof, nor any of their employees, makes any warranty, express or implied, or assumes any legal liability or responsibility for the accuracy, completeness, or usefulness of any information, apparatus, product, or process disclosed, or represents that its use would not infringe privately owned rights. Reference herein to any specific commercial product, process, or service by trade name, trademark, manufacturer, or otherwise, does not necessarily constitute or imply its endorsement, recommendation, or favoring by the United States Government or any agency thereof. The views and opinions of authors expressed herein do not necessarily state or reflect those of the United States Government or any agency thereof. 
ORNL/SPR-2017/577

CRADA/NFE-12-04010

Building Technologies Research and Integration Center

Development and Implementation of Air Barrier Systems for New and Existing Buildings

Diana E. Hun

Andre O. Desjarlais

Laverne Dalgleish

December 2017

\author{
Prepared by \\ OAK RIDGE NATIONAL LABORATORY \\ Oak Ridge, Tennessee 37831-6283 \\ managed by \\ UT-BATTELLE, LLC \\ for the \\ US DEPARTMENT OF ENERGY \\ under contract DE-AC05-00OR22725
}




\section{TABLE OF CONTENTS}

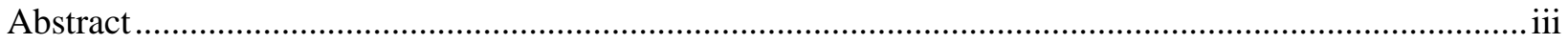

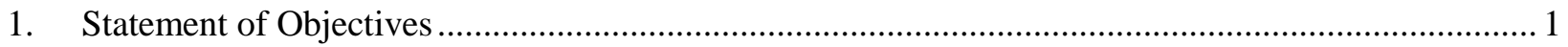

2. Technical Discussion of Work Performed by All Parties .......................................................... 1

2.1 Task 1: Assess the effect of air leakage on energy use and material durability ..................... 1

2.2 Task 2: Estimate the relative contribution of air leakage paths ........................................ 2

3. Plans for Future Collaboration....................................................................................... 2

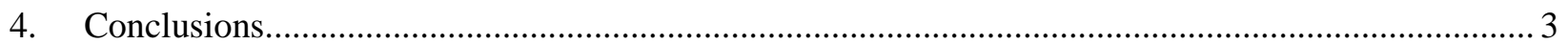

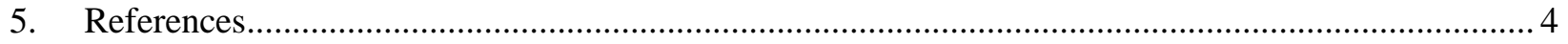




\begin{abstract}
A Cooperative Research and Development Agreement (CRADA) was established between Oak Ridge National Laboratory (ORNL) and the Air Barrier Association of America (ABAA) to assess key aspects that influence the performance of air barrier systems commonly used in residential and commercial buildings. This collaboration was intended to include laboratory experiments and evaluations in a natural exposure test facility, as well as building envelope retrofits that improved the airtightness of existing buildings. Even though the Department of Energy discontinued funding this work after two years, the gathered results provided insight on the effect of air leakage on energy use and material durability, as well as the contribution of common air leaks to energy consumption. Furthermore, ORNL and ABAA have continued collaborating in other projects such as the development of a free online calculator that estimates energy and cost savings due to improvements in airtightness.
\end{abstract}




\section{STATEMENT OF OBJECTIVES}

Airtight construction is an essential component in energy efficient buildings. Retrofit programs for existing buildings and building code requirements for new construction promote the reduction of air leakage through the building envelope because infiltration and exfiltration are responsible for close to $4 \%$ of the total energy used in the US (DOE 2014). To help achieve airtight structures, manufacturers have developed different air barrier technologies to meet the needs of various types of construction. Moreover, the Air Barrier Association of America (ABAA) was created in 2001 to promote standards that will ensure effective air barrier systems in buildings.

Laboratory experiments have shown that air barriers significantly reduce airflow when tested at the material level. Nevertheless, comprehensive research on air barriers at the assembly level (i.e., air barrier material with accompanying components) and system level (i.e., entire building enclosure) are at a developing stage because few manufacturers have access to the required technical expertise and/or experimental facilities. Consequently, a Cooperative Research and Development Agreement (CRADA) between Oak Ridge National Laboratory (ORNL) and ABAA was proposed to assess key aspects that influence the performance of air barrier systems commonly used in residential and commercial buildings. More specifically, the objectives of this collaboration were to:

1. Quantify the energy benefits due to air barriers,

2. Assess the effect of air leakage on the durability of building materials,

3. Estimate the relative contribution of typical air leakage paths,

4. Evaluate techniques to seal main air leakage sites, and

5. Develop methods to incorporate air barriers into the retrofit of existing buildings.

Results from this research will enhance energy efficiency in both new and existing buildings by:

1. Improving air barrier systems, and

2. Identifying cost-effective means to increase airtightness.

The CRADA between ORNL and ABAA was expected to be a 5-year collaboration that formally started in 2012 and was intended to end in 2017.

\section{TECHNICAL DISCUSSION OF WORK PERFORMED BY ALL PARTIES}

Field and laboratory experiments were undertaken to accomplish the project's objectives. The following sections describe the conducted tasks and their outputs.

\subsection{TASK 1: ASSESS THE EFFECT OF AIR LEAKAGE ON ENERGY USE AND MATERIAL DURABILITY}

Field experiments were initiated in FY11 at the Syracuse Natural Exposure Testing (NET) facility to estimate the effect of three levels of air leakage rates on energy consumption in buildings and on the durability of building materials. The air leakage levels that were investigated are the required values for air barrier materials (Level $1 \cong 0.02 \mathrm{~L} / \mathrm{s} / \mathrm{m}^{2}$ at $75 \mathrm{~Pa}$ ), air barrier assemblies (Level $2 \cong 0.2 \mathrm{~L} / \mathrm{s} / \mathrm{m}^{2}$ at 75 $\mathrm{Pa}$ ), and air barrier systems (Level $3 \cong 2 \mathrm{~L} / \mathrm{s} / \mathrm{m}^{2}$ at $75 \mathrm{~Pa}$ ). 
Evaluations at the NET facility included the eight air barrier types that are typically used in residential and commercial buildings: fluid-applied membranes, insulating sheathings, non-insulating sheathings, interior air barriers, mechanically-fastened membranes, self-adhered membranes, spray-applied foam, and sealants with backup structure. ABAA built three panels for each of the air barrier types to represent one of the air leakage levels under consideration. Additionally, the study included four control specimens. ORNL instrumented each of the panels with temperature, heat flux, relative humidity, moisture content, and pressure sensors. Data were collected for twelve months. Results are reported in "Effects from the Reduction of Air Leakage on Energy and Durability."

\subsection{TASK 2: ESTIMATE THE RELATIVE CONTRIBUTION OF AIR LEAKAGE PATHS}

Laboratory experiments were conducted to evaluate the relative effect of air leakage sites that are typically found in walls. Specimens that were $8 \mathrm{ft}$ by $8 \mathrm{ft}$ were built by ABAA to represent residential construction. More specifically, the wall construction consisted of wood stud framing with oriented strand board exterior sheathing. These are the air leakage paths that ORNL evaluated based on input from air barrier manufacturers:

1. Exterior sheathing joints at studs

2. Interface between bottom plate and wood sheathing at floor

3. Interface between top plate and rim joist

4. Joints between studs and top/bottom plates

5. Interface between exterior sheathing and top/bottom plates

6. Penetrations
a. Junction boxes
b. Electrical conduits

Air flow through these imperfections were characterized by subjecting the wall specimens to several pressure differentials. Imperfections were evaluated by installing a group of them on a specimen and back calculating their individual contribution to the total air flow. Experiments were performed by ORNL at Tremco's Sustainable Building Solutions Test Facility in Cleveland, OH. Results are reported in "Evaluation of Air Barriers for Residential Buildings."

\section{PLANS FOR FUTURE COLLABORATION}

Although this project was intended to span until 2017, the Department of Energy (DOE) discontinued funding this work in 2014. Therefore, the two tasks that are described in the previous section were the only ones completed, and tasks that involved the evaluation of commercial walls in laboratory experiments and retrofit studies in existing buildings were not conducted. Nevertheless, the collaboration between ABAA and ORNL has continued through other venues. ABAA contracted ORNL and the National Institute of Standards and Technology (NIST) to develop a free online calculator that estimates energy and cost savings due to improvements in airtightness for certain DOE commercial prototype buildings $^{1}$ (Shrestha et al. 2016). The calculator may be useful to building owners and designers when trying to decide the airtightness level they want to target. This work has been ongoing for about two years, and was recently expanded based on positive input from the construction industry.

\footnotetext{
${ }^{1}$ http://www.airbarrier.org/technical-information/energy-savings-calculator/
} 


\section{CONCLUSIONS}

The collaboration between ORNL and ABAA provided results from assessments in a natural exposure test facility and laboratory evaluations. Findings include insight on the effect of air leakage on energy use and material durability, as well as the contribution of common air leaks to energy consumption. Because DOE discontinued funding this work after two years, tasks that involved the evaluation of commercial walls in laboratory experiments and retrofit studies in existing buildings were not conducted. However, ORNL and ABAA have continued collaborating in other projects such as the development of a free online calculator that estimates energy and cost savings due to improvements in airtightness. 


\section{REFERENCES}

DOE. 2014. Windows and Building Envelope Research and Development: Roadmap for Emerging Technologies. Washington, DC: US Department of Energy.

Hun DE, Childs PW, Atchley JA, Desjarlais AO. 2013. Effects from the Reduction of Air Leakage on Energy and Durability. ORNL/TM-2013/507. Oak Ridge National Laboratory, TN, USA.

Hun DE, Spafford P, Desjarlais AO. 2014. Evaluation of Air Barriers for Residential Buildings. ORNL/TM-2013/604. Oak Ridge National Laboratory, TN, USA.

Shrestha SS, Ng L, Emmerich S, Hun D, Desjarlais A, Dalgleish L. 2016. Online Airtightness Savings Calculator for Commercial Buildings in the US, Canada and China. In: Proceedings from the Buildings Conference XIII, Clearwater, FL. 